TTR

Traduction, terminologie, rédaction

\title{
Redefining Translation Spaces in the Soviet Union: From Revisionist Policies to a Conformist Translation Theory
}

\section{Gleb Dmitrienko}

Volume 32, numéro 1, 1er semestre 2019

Traduction et politique(s)

Translation, Politics and Policies

URI : https://id.erudit.org/iderudit/1068019ar

DOI : https://doi.org/10.7202/1068019ar

Aller au sommaire du numéro

\section{Éditeur(s)}

Association canadienne de traductologie

ISSN

0835-8443 (imprimé)

1708-2188 (numérique)

Découvrir la revue

Citer cet article

Dmitrienko, G. (2019). Redefining Translation Spaces in the Soviet Union: From Revisionist Policies to a Conformist Translation Theory. TTR, 32(1), 205-229. https://doi.org/10.7202/1068019ar

\section{Résumé de l'article}

En raison de son potentiel de manipulation et de sa capacité à créer des distorsions délibérées, la traduction a toujours joué un rôle important dans de nombreux projets qui impliquaient la manipulation de cultures et d'identités. D'ailleurs, dans certains contextes politiques et sociaux, la traduction pourrait servir de système propulseur aux interventions délibérées des agents de pouvoir visant à changer et à exploiter les états d'esprit, les cultures et les identités au sein d'un peuple, dans le cadre d'un régime politique en vigueur. La traduction devient indispensable à de telles stratégies manipulatrices, parce qu'elle contribue à la propagation d'une idéologie donnée, et ce, dans différentes langues, et qu'elle aide à créer et à maintenir une identité conformiste soutenue par l'État. Cet article analyse ce type de cas par rapport à l'évolution de la traduction et de la traductologie soviétiques dans un contexte totalitaire. En examinant le rôle de la traduction dans une série de réorientations culturelles forcées qui font partie de l'histoire nationale russe, nous explorons comment la traduction a été utilisée pour créer et imposer une identité soviétique supranationale. Nous montrons aussi comment les débats autour des politiques et de la « bonne " méthode de traduction qui convient à la réalité de l'État socialiste ont abouti à l'émergence de deux écoles de pensée opposées : l'une favorisant une approche de linguistique structuraliste et l'autre, une approche littéraire. En présentant notre analyse du discours traductologique russe du point de vue de l'idéologie du régime totalitaire soviétique, nous démontrons comment chacune des écoles manipulait l'idéologie communiste dans sa course pour la reconnaissance officielle. Nous expliquons également comment le structuralisme linguistique est devenu le courant théorique dominant en traduction soviétique et comment l'approche rivale de la traduction « réaliste » est tombée dans l'oubli.
Ce document est protégé par la loi sur le droit d'auteur. L'utilisation des services d’Érudit (y compris la reproduction) est assujettie à sa politique d'utilisation que vous pouvez consulter en ligne.

https://apropos.erudit.org/fr/usagers/politique-dutilisation/ 


\title{
Redefining Translation Spaces in the Soviet Union: From Revisionist Policies to a Conformist Translation Theory
}

\section{Gleb Dmitrienko}

Université de Montréal

\begin{abstract}
Due to its manipulative potential and ability to create deliberate distortions, translation has become instrumental for many projects that involve culture and identity manipulations. In some political and social contexts, translation may serve as a driving force for deliberate and consistent intervention by power holders in order to modify and exploit the nation's mindset, its cultures and identities for political purposes. For such manipulative strategies, translation becomes essential as it contributes to the propagation of a given ideology by conveying it in different languages, and aids in creating and sustaining a statesponsored conformist identity. This paper analyzes such a case in relation to the evolution of Soviet translation and translatology in the context of a totalitarian state. By examining the role of translation in a series of forced cultural reorientations that are a part of Russian national history, we explore how translation was used to impose a supranational Soviet identity. We also present how the ongoing disputes surrounding translation policies and translation methods in the Socialist state resulted in the emergence of two opposing schools of thought: one that studied translation within the paradigms of structuralist linguistics, and the other that advocated for a literary approach. By framing our analysis of the Russian translatological discourse within the context of Soviet ideology and the rise of totalitarianism, we demonstrate how each of the schools manipulated the official state ideology in a struggle for recognition. We also seek to explain how linguistic structuralism came to represent the dominant theoretical framework for Soviet translation science, thus relegating to oblivion the "realist" approach to translation.
\end{abstract}

Keywords: translation, identity, culture planning, Soviet Union, totalitarianism

\section{Résumé}

En raison de son potentiel de manipulation et de sa capacité à créer des distorsions délibérées, la traduction a toujours joué un rôle important dans de nombreux projets qui impliquaient la manipulation de cultures et d'identités. D'ailleurs, dans certains contextes politiques et sociaux, la traduction pourrait 
servir de système propulseur aux interventions délibérées des agents de pouvoir visant à changer et à exploiter les états d'esprit, les cultures et les identités au sein d'un peuple, dans le cadre d'un régime politique en vigueur. La traduction devient indispensable à de telles stratégies manipulatrices, parce qu'elle contribue à la propagation d'une idéologie donnée, et ce, dans différentes langues, et qu'elle aide à créer et à maintenir une identité conformiste soutenue par l'État. Cet article analyse ce type de cas par rapport à lévolution de la traduction et de la traductologie soviétiques dans un contexte totalitaire. En examinant le rôle de la traduction dans une série de réorientations culturelles forcées qui font partie de l'histoire nationale russe, nous explorons comment la traduction a été utilisée pour créer et imposer une identité soviétique supranationale. Nous montrons aussi comment les débats autour des politiques et de la «bonne» méthode de traduction qui convient à la réalité de l'État socialiste ont abouti à l'émergence de deux écoles de pensée opposées : l'une favorisant une approche de linguistique structuraliste et l'autre, une approche littéraire. En présentant notre analyse du discours traductologique russe du point de vue de l'idéologie du régime totalitaire soviétique, nous démontrons comment chacune des écoles manipulait l'idéologie communiste dans sa course pour la reconnaissance officielle. Nous expliquons également comment le structuralisme linguistique est devenu le courant théorique dominant en traduction soviétique et comment l'approche rivale de la traduction «réaliste» est tombée dans l'oubli.

Mots-clés : traduction, identité, interventions culturelles, Union soviétique, totalitarisme

\section{Introduction}

In 2017 the world celebrated the centennial of the Socialist Revolution in Russia, which was not only a pivotal point in its national history, but also one of the largest projects of forced cultural reorientation. ${ }^{1}$ As such, the historical examples of the Russian Revolution and the subsequent creation of the first Socialist state can both be used for the study of various social and cultural phenomena, like national and supranational identities, de- and re-identification, cultural and axiological reorientation (both voluntary and forced), socio-economic and political reforms associated with Marxism-Leninism and, of course, the rise of totalitarianism.

The drastic geopolitical and social transformations that befell Russia at the beginning of the $20^{\text {th }}$ century may be equally analyzed for the study of translation and its role in the propagation of the state ideology, as well as in the realization of centralized culture-planning

1. Although the concept of cultural reorientation is not new in political (Braman et al., 2005), historical (Higham, 2001; Berghahn, 2006), and post-colonial discourse (Khān, 2001; Asagba, 2011), it has not yet been applied to the Russian post-revolutionary context. 
operations. In the advent of the Socialist state, translation served the needs of the Communist Party's program by facilitating the import and appropriation of the canonical works of Marxism, which were used to build the communist ideology. Lenin himself translated and commented on the works of Marx, Engels and other influential Social Democrats, such as Kautsky, Becker, and Dietzgen (Lenin, 1965, vol. 10-12). Furthermore, for a society seeking to modernize its industry and to boost the economy, translation was instrumental in the acquisition of knowledge on foreign cultures and on the latest advances in technology. "We must learn from our enemies," Lenin wrote in his pamphlet in 1919, "so as to acquire the fruits of their culture" (1972, n.p.). Lastly, being a perfect tool for political manipulation, translation in the Soviet Union could provide controllable access to the world's cultural heritage which was partially achieved through extensive translation and publishing campaigns-like the one that was launched in 1919 with the establishment of the Vsemirnaya Literatura Publishers (Gorky, 1919). ${ }^{2}$

In this paper, we will explore the general role of translation in the revolutionary transformation of Russia in the $20^{\text {th }}$ century, as well as its contribution to the creation of the Soviet state and the making of the Socialist (proletarian) identity. Through an analysis of the historical role of translation in the Soviet Union from 1919 until 1950, we will understand the context in which Russian translatology has evolved. Then, by focusing on the theoretical debates around translation during the later Stalinist period (1950-1953), we will demonstrate how the disputes surrounding the ideologically compliant translation methods in the Soviet Union resulted in the rise of a linguistic approach to translation. This rise has sparked a theoretical and political confrontation between the "linguistic" school of thought and the existing school of literary translation, which drew its inspiration from the long-standing tradition of Russian formalism, literary criticism, and literary translation. However, in the context of the Stalinist regime, it was ideological conformism, rather than a theoretical approach to translation per se, that defined the future of the Soviet theory of translation. By framing our analysis of the translation discourse within the context of Stalinism, we will demonstrate how both schools manipulated the official state ideology in a struggle for recognition. Through the historical analysis of this debate, we will

2. We will talk about Vsemirnaya Literatura later in this article. 
also try to explain how linguistic structuralism came to represent the dominant theoretical framework for the institutionalized Soviet translatology, thus relegating to oblivion the "realist" approach to translation.

\section{The October Revolution and the (Re)-modelling of the Nation(s)}

\subsection{Rebuilding the State}

After the victory of the Socialist Revolution, the Bolsheviks could not be satisfied with a simple restoration of the pre-existing social structures and institutions. Their revolutionary agenda required a fundamental reformation of the social and political structures and a complete reorganization of the economic relations and other aspects of life in Russia. The Bolsheviks sought to establish a new social order, a "specific form of a republic that [was] not only to remove the monarchical form of class rule, but class rule itself" (Lenin, 1917, n.p.). ${ }^{3}$ However, the reorganization of the state into a class-free society would have been impossible without preliminary unification of all social elements around the proletariat, which was viewed as "the only class that can unite all the working and exploited people in the struggle against the bourgeoisie" (ibid.). Class unification required education of the masses, both culturally and politically, as well as the reconstruction of multiple national identities around Communist ideas, which would eventually facilitate overcoming social segregation and merging various national identities into a supranational identity of the emancipated working class. Moreover, the Bolsheviks shared Karl Kautsky's general belief that "the economic development and the class struggle create, not only the conditions for socialist production, but also, and directly, the consciousness of its necessity" (cited in Lenin, 1901, n.p.; italics by Kautsky). Yet, in the context of cultural belatedness, endemic poverty and illiteracy, the introduction of political culture was a real challenge:

In the beginning, we had to teach the workers the $\mathrm{ABC}$ [sic], both in the literal and in the figurative senses. Now the standard of political literacy has risen so gigantically that we can and should concentrate all our efforts on the more direct Social-Democratic objectives aimed at giving an organized direction to the revolutionary stream. (Lenin, 1905, n.p.)

3. Although we mainly refer to the works of Lenin translated and published by the Lenin Internet Archive, some publications, like "State and Revolution," have alternative paperback editions. Nevertheless, for consistency of the references and because of the wider accessibility of online resources, we will be referring to primary sources provided in English translation by the Marxists Internet Archive. 
To achieve political education of the proletariat, it was necessary to change the mass' mindset and raise the revolutionary civic awareness of the people who were supposed to form the socialist nation.

\subsection{Rebuilding the Nation's Identity}

From a historical perspective, the Revolution and the realization of the Bolsheviks' Socialist program may be regarded as an example of forced cultural reorientation and thus be examined in relation to similar cases in Russian national history: the Christianization of the Kievan Rus' by the Grand Prince Vladimir in 988 and the Westernization of the Russian Tsardom by Peter I in 1721-1725 (Kliuchevsky, 1937). The historical parallels which can be drawn from Russia's Christianization, Westernization and Bolshevization ${ }^{4}$ make us believe that all three projects form a continuum of historical manipulations of the Russian national identity, its core values and cultural repertoire. Each involved a centralized program of social and cultural reorganization, which required the nation to re-evaluate its identity and conform, prospectively or retrospectively, to the changed or targeted conditions. From this historical perspective, the projects of cultural reorientation bear some resemblance to culture-planning operations-a concept introduced by Itamar Even-Zohar to describe "deliberate acts of intervention, either by power holders or by 'free agents', into the extant or crystallizing repertoire" (2002, p. 45). Although the notion of culture planning was further developed by Gideon Toury-who noted that such interventions do not only influence literary repertoires but also cause behavioural changes in the related communities (2005, p. 9) - and even though it has already been applied to the Soviet literary production (Witt, 2011), we argue that the notion of culture reorientation requires more attention as it is much wider than culture planning. Therefore, to delimit these notions, we propose our ad hoc definition of cultural reorientation:

Cultural reorientation may be defined as a centralized project implying deliberate manipulations of a nation's identity and culture in favour of the needs of the ruling class and its current political, cultural or socioeconomic agenda. Cultural reorientation usually takes place in the pivotal moments of national history and precedes or immediately follows fullscale reformations or reorganization of habitual social structures and practices.

4. By "Bolshevization," we mean the final ideological victory of Marxism and Leninism. The term was proposed by Grigory Zinoviev at the Comintern's Fifth Congress (Cannon, 1924). 
Alternatively, we may approach this sociocultural phenomenon from a sociological perspective by adopting, for example, Pierre Bourdieu's terminology and vision of the field and the habitus (1990, p. 54). Our definition would then read as follows:

Cultural reorientation may be seen as a process for the regulation of social practices, which implies the transposition of objective structures of the field into the subjective perception of this field by its agents, affecting their thoughts and actions (babitus and doxa).

With regard to manipulation using habitus as a part of cultural reorientation, we should emphasize that, although Christianization, Westernization and Bolshevization aimed at reconciling the masses with changes to social arrangement, the methods used in these projects were different. While Christianity was imposed by force (Cross and Sherbowitz-Wetzor, 1953) and the Westernization project relied on rudimentary legislative foundations (Anisimov, 2015), neither of these methods would have worked in the revolutionary context of 1917. Moreover, the use of brutal force against the working class would have produced a reverse effect on the Socialist project. The only way the Bolsheviks could win public support was by transforming the politically inert populace into an emancipated and socially active class, and this could only be achieved by educating people in a certain fashion and reconstructing their identity.

In addition to the educational objective, the manipulations of the Russian identity had to contribute to the resolution of the "nationalities question" (Stalin, 1920). Acknowledging that the centrifugal forces generated by nationalist movements would jeopardize the creation and further development of a unified Socialist state, the Bolsheviks searched for a means to minimize the threat of nationalism. The removal of segregation along ethnic or cultural lines in the Socialist State was the solution. This implied replacing traditional national identities with a new cosmopolitan identity associated with a unified social class, rather than with any particular nationality, ethnos or culture.

\subsection{Rebuilding the Culture}

While the Bolsheviks' ideology of class struggle sought to indoctrinate people and to turn them against the former oppressors (Lenin, 1917, n.p.), another solution was to unite the proletariat along cultural lines. It involved the introduction of a brand-new proletarian culture that was supposed to supplant cultural norms, choices and attitudes related to the old ruling order and demonstrate "that the 
Marxist world outlook is the only true expression of the interests, the viewpoint, and the culture of the revolutionary proletariat" (Lenin, 1920, n.p.). Following Lenin's directive, which required that "all educational work in the Soviet Republic, in the field of political education in general and in the field of art in particular, be imbued with the spirit of the class struggle being waged by the proletariat for the successful achievement of the aims of its dictatorship" (ibid.), the People's Commissariat of Enlightenment, Narkompros, took the lead in introducing the Communist ideology through well planned and masterfully orchestrated literacy campaigns. Additionally, in order to lay the theoretical foundation for the Communist agenda, Narkompros presented a paradigm of Scientific Communism, which encompassed the investigation of laws, forms of class struggle and Socialist development, and which quickly became the only recognized framework for Soviet science. ${ }^{5}$

Meanwhile, the situation in the field of artistic production also required a systemic approach. Although Art was proclaimed "an element of class consciousness and a medium of class unification and consolidation of class forces" (Bogdanov, 1924, p. 98; our trans.), the disputes over the principles for constructing the proletarian culture revealed the first signs of disagreement among the members of the vanguard Party. The main ideologists of the newly formed Proletcult movement ${ }^{6}$ that sought to create genuine forms of proletarian culture insisted on the fact that:

Our proletarian culture is replacing bourgeois culture. And it's natural to assume that it will be its opposite. The content of contemporary experience does not even fit into existing forms of cognition. New forms are needed [a]nd only the proletariat will be able to fulfill this colossal creative work. (Lebedev-Polyansky, 1918, pp. 51-52)

The idea of creating a unique culture of the working class has not however been supported by the ideologists of Marxism-Leninism to whom such extreme exaltation of the proletariat seemed unrealistic. Thus, Lenin opposed cultural rejectionism of Proletcult, pointing to the fact that:

Marxism has won its historic significance because, far from rejecting the most valuable achievements of the bourgeois epoch, it has assimilated

5. For more details on the educational and culture-planning activities of Narkompros, see Fitzpatrick (2002).

6. Short for "proletarian culture." In other sources, may also appear as Proletkult. 
and refashioned everything of value in the more than two thousand years of the development of human thought and culture. Only further work on this basis can be recognized as the development of a genuine proletarian culture. (1920, n.p.)

Similarly, Trotsky argued in Literature and Revolution that

proletarian culture and art will never exist, because the proletarian regime is temporary and transient, [but] it is laying the foundations of a culture which is above classes and which will be the first culture which is truly human. $(1925, \text { pp. } 32-33)^{7}$

While the disputes around the principles for constructing the proletarian culture were something that the Communist Party could tolerate, it could never allow Proletcult to self organize in full disassociation from the State. Therefore, in reaction to the attempt of Proletcult to lobby for its autonomy, the Central Committee passed a unanimous resolution disapproving

[...] as theoretically unsound and practically harmful, all attempts to invent one's own particular brand of culture, to remain isolated in self-contained organizations, to set up a Proletcult "autonomy" within establishments under the People's Commissariat of Enlightenment. On the contrary, all Proletcult organizations must be bound to act as auxiliary bodies of the People's Commissariat of Enlightenment, and to accomplish their tasks under the general guidance of the Commissariat and of the Russian Communist Party. (Lenin, 1920, n.p.)

In other words, this meant that Proletcult organizations would be disbanded and that the responsibility for the further cultural reorientation of the masses would now be entrusted to Narkompros.

\subsection{Socialist Realism}

Drawing lessons from Proletcult's political mistakes, the functionaries of Narkompros would immediately abandon the idea of creating a class-exclusive proletarian culture. On the contrary, as a political institution empowered to supervise public education, Narkompros would rather try to translate the problem of cultural reorientation into the field of its expertise and approach it as an educational task. Within its operational framework - now extended to the field of cultural production - the Commissariat could make use of the same regulatory mechanisms which it had already put in place for Soviet

7. Although this point of view was subsequently criticized as part of the Stalinist political campaign against Trotskyism, at that moment, it reflected the position of the Bolsheviks on the matter. 
science and compulsory public education. Seeking to establish state control over artistic production and cultural education, Narkompros introduced a centralized system uniting different professional associations, such as the unions of Soviet writers, artists, composers, architects and others, with departments for "cultural Enlightenment" (Kultprosvet) responsible for leading, supervising and financing any culture-oriented activity in the Soviet State. Moreover, in order to make sure that Soviet Art reflected the ideas, thoughts and aspirations of the Communist Party, Narkompros adopted a Marxism-informed cultural doctrine of Socialist Realism. The doctrine was meant to set up some guiding principles for every type of creative work in the country, therefore becoming the main ideological framework for different kinds of artistic expression—-just like Scientific Communism was for Soviet science.

As a cultural doctrine, Socialist Realism sought to limit popular culture to a highly regulated faction of creative expression, which was understandable to the proletariat and which promoted Soviet ideals through the creation of ideological and class-relevant content and by depicting it in an agreeable fashion (Nelson and Grossberg, 1988). As art was proclaimed an educational matter, it was used fully for the purposes of Soviet cultural propaganda which consisted in translating a positive image of the Soviet Union and boasting of its achievements. The "realist" illustrations of the Party's accomplishments, such as the liberation of the working class and the creation of a better living environment were supposed to demonstrate the superiority of the Communist political system. Hence, the Party was thorough in the selection of depicted material:

We do not photograph life. Realism means that we make a selection from the point of view of what is essential [...] Select all phenomena which show how the system of capitalism is being smashed, how socialism is growing, not embellishing socialism but showing that it is growing in battle, in hard toil, in sweat. Show how it is growing in deeds, in human beings. [...] That is what socialist realism means. (Radek, 1934, n.p.)

While following the standards of Socialist Realism in visual and performing arts was relatively simple, the literary production in the Soviet republic required serious reconsideration. Obviously, literature could not be simply recreated or "imbued with the spirit of the class struggle" in accordance with the Leninist conception (Lenin, 1920, n.p.). Additionally, most discussions about Socialist Realism did not provide any definition of the notion. Even the Head of the department 
of Soviet culture and propaganda Alexey Stetsky could only present personal interpretations of the doctrine:

Socialist realism is not some set of tools that are handed out to the writer for him to make a work of art with. Some writers demand that they be given a theory of socialist realism complete in all its details. [...] We must show socialist realism in those works of art which Soviet writers produce. (1934, n.p.)

As for the application of Socialist Realism to literary production, in most cases, it could only be traced in conformity to particular features that distinguished a Socialist Realist novel from a Western or pre-revolutionary Russian novel. Put simply, these distinctive features can be reduced to the following:

(1) Depiction of the hero's quest for impersonality and struggle to "become one with" his Marxist-Leninist role.

(2) Highly formulaic plotting and style.

(3) Themes that Western readers deem to be unamenable to novelistic treatment.

(4) Inclusion of political sermons, often in high-flown rhetorical language, even in fiction.

(5) Lack of irony.

(6) Strong closure and a mandatory happy or "constructive" ending. (Morson, 1979, p. 122)

Abiding by Lenin's resolution which aimed to "assimilate and refashion the most valuable achievements of the bourgeois epoch" (Lenin, 1920, n.p.), Narkompros had to develop a strategy for a critical revision of the existing literary repertoire. Furthermore, there was a clear need for a new state-controlled access to the world's literary heritage. Such access would ensure that all imported and exported literature would be screened through the official state ideology and imbued, if needed, with the ideals of the proletarian cultural outlook. From this perspective, the application of the principles of Socialist Realism to literary production in the Soviet Union, in addition to the related revisionist policies, easily fell under what Even-Zohar has called culture-planning operations or "deliberate acts of intervention by power holders into an extant or a crystallizing repertoire" (2002, p. 45). 


\section{Revisionist Policies and the Rise of Translation}

It is not surprising that the mission to reorganize Soviet literature in conformity with the tenets of Socialist Realism befell the Soviet Writers' Union and, in particular, its Translation Division. It is worth mentioning that, although the Union was created in 1934, the problems of translation as a means of applying revisionist policies had already been discussed in the Soviet Union for the past fifteen years. In 1919, a group of writers and literary scholars, inspired and led by an eminent Russian writer and political activist Maxim Gorky, established a publishing house called Vsemirnaya literatura [World Literature] with the intention to publish some 4000 titles of freshly translated literature-mostly the classics of the world literary heritage (Levin, 1962). Although the publishing house issued only 120 titles instead of 4000, the efforts put into Vsemirnaya literatura, both in terms of translation and publishing, were enormous. In fact, specifically referring to Soviet attitudes toward American writing, Deming Brown notes that

The Soviet regime fostered the publication of a quantity and variety of American literature much greater than that which had been available before the revolution. Despite a censorship which has excluded many works that militate against the official Soviet interpretation, America, to some extent, was permitted to speak for herself through translation. (1962, p. 19)

When discussing Vsemirnaya literatura, it is impossible not to mention the creation of a workshop for literary translation and the publication of the first Soviet manual on literary translation, Principy hudozhestvennogo perevoda [The Principles of Literary Translation], by writer and literary critic Kornei Chukovsky and poet Nikolay Gumilev (1919). In this thirty-page booklet, the authors tried to draft some guidelines for translators, both in prose and poetry, by presenting translation as a process of recreation of a literary artifact in another language, where the quality and the spirit of the source text should be preserved. They also argued that the translator is free to choose the means of expression needed to transpose the spirit of the source text into a new form. Formalist in its approach, Principy, however, played a significant role in the future development of the Soviet translation method, for it was the first known "manual" to translation as a new discipline (Balliu, 2005, p. 936). However, despite the historical, theoretical and didactic value of the manual, its calls to transpose the 
spirit of a source text into the Soviet reality were easily interpreted as counter-revolutionary. ${ }^{8}$ As a result, the first attempt to organize paraprofessional training for translators in Soviet Russia failed for political reasons. With the beginning of the Civil war, Vsemirnaya literatura could not, for its part, acquire resources to support its translation and publishing project, and consequently shut its doors forever in 1924. Nevertheless, the existence of such a precedent meant that, by the 1930s, Soviet translators already had some literary and political experience in implementing policies for cultural intervention.

The introduction of Socialist Realism in 1934 and its establishment as the main artistic method of Soviet literature (Luppol et al., 1990 [1934]) required the Soviet literary workers to develop new representative expressions fully compatible with the tenets of Socialist Realism. Coincidentally, for Soviet translation, the introduction of Socialist Realism became intertwined with processes of "intense selfreflection and self-assessment of translators as cultural workers within Soviet culture, often articulated from a point of perceived inferiority in relation to original literary production" (Witt, 2016, p. 52). This reassessment of the translators' role in the creation of the Soviet culture was mostly due to the adoption of Stalin's doctrine which proclaimed "the final victory of Socialist Construction in one country [USSR]" (Stalin, 1978 [1938]) and therefore put a hard stop to the Leninist policies for the support of the International Communist Movement. The reverse in foreign policies associated with Stalin's Socialist doctrine resulted in ideological alienation of the USSR from the outer world, which also impacted the translation policies within the country. Upon the adoption of Stalin's doctrine, the focus of Soviet translation policies shifted inwards. Following the call of the Writers' Union to contribute to the process of organizing All-Union literature, the Translation Division accepted the challenge of launching several largescale projects for translation from and into the national languages of the multinational Soviet state. As noted by Susanna Witt:

translation from various languages was not only to contribute to the creation of a global Socialist Realist canon, but also to the canon of "representative" expressions of national cultures from within the empire (thus also becoming a matter of nationalities policy). (2011, p. 151)

The theoretical basis for this translation endeavour was reflected in the keynote speech "Cultural revolution and the problems of lit-

8. Especially in light of the highly politicized trial and subsequent execution of Nikolai Gumilev in 1921. 
erary translation" delivered during the First All-Union Translators' Conference (1936) by literary and theatre critic Iogann Altman. In his address to the conference, Altman translated the Soviet political discourse into guiding principles for Soviet translators. In order to bring Soviet translation into the current of recent anti-formalist campaigns, he also proclaimed that Socialist Realism was a means of struggle "against naturalism, formalism, impressionist, exoticizing and stylizing translation" (Altman, cited in Witt, 2016, p. 53). However, the initial call hardly provided any clear definition of Socialist Realism as a literary method, nor did it specify how it might be applied to translation. Mostly for that reason, as noted by Witt, the term and the method of Socialist Realism in relation to translation was not mentioned again until the early 1950s (ibid.).

With the beginning of the Second World War, the role and significance of translation practises were revised once more according to their relevance to the wartime reality. The demand for literary translators was low, unlike the demand for military and "pragmatic" translation. In order to meet the rising need for specialists, the Moscow Military Institute of Foreign Languages launched a handful of short-term training programs for translators and interpreters. At the same time, the post-war reality explicitly articulated the need for a critical reassessment of the existing translation methods, as well as for the development of a systemic approach to theorizing about translation practice. The resumed activities of the Translators' Section were marked with an appeal for a consistent theory of translation which would "prescribe and educate as well as provide the normative base for the evaluation of the quality of translations" (Azov, 2012, pp. 134-135; our trans.).

\section{Toward a Soviet Theory of Translation}

\subsection{A Linguistically Informed Theory}

The first attempt to lay a strictly scientific foundation for a Soviet translation theory was made in 1948, during the Translation Division panel. The philologist and translator Andrei Fedorov-who had previously co-authored one of Chukovsky's books on literary translation (Chukovsky and Fedorov, 1930) - suggested that translation could be approached from a linguistically informed point of view which recognizes the principle of translatability and acknowledges "functional and semantic correspondences" between a translation and the original text (cited in Witt, 2016, p. 54). Such an approach, he 
argued, should rest upon "a systemic use of facts from the history of literature, language and other humanistic knowledge" (ibid.).

It seems that although Fedorov began his career as a partisan of the literary school of translation (see Chukovsky and Fedorov, 1930; Fedorov, 1941), he had to search for compromises between his views and the political realia. Drawing from past translation experience, and particularly from the case of Vsemirnaya literatura, Fedorov clearly understood that Soviet censorship would not tolerate any voluntarism or subjectivity. The Socialist reality dictated that a new translation theory-apart from being conformist-should be built upon on a theoretical platform which could consolidate various views on translation and its methods, while guaranteeing impartial interpretation and clear rendering of the source text. Furthermore, throughout the Second World War and the early post-war years, which were marked with the rise of international organizations and the wide involvement of the USSR in external political affairs, the translation activity in the USSR started to shift gradually from literary to non-literary. This shift also influenced the selection criteria for the new translation theory; with the demand for non-literary translation constantly growing, the new theory was supposed to be applicable to a greater variety of types and genres of texts than permitted by a literary informed theory.

Adopting Gorky's attitude to language as a "primary element of literature" (1955, p. 672; our trans.), Fedorov decided to break his allegiance to the literary school of translation and build his theory on a linguistic platform which, according to some researchers (Fokin, 2016), became the main controversy of Fedorov's post-war career as a translation scholar. Openly supported by Gorky, the linguistic approach seemed to be the best choice in constructing an ideologically compliant translation theory and a "particular scientific discipline" which would be capable of

tracing the regularities in the relations between the original and the translation, generalizing findings from observations of individual cases of translation and serving as a theoretical foundation for translation practice that could be guided by it in looking for needed means of expression and choosing them, and could turn to it for arguments and evidence in favour of specific solutions. (Fedorov, 1953, p.12; cited in Garbovskiy and Kostikova, 2012; trans. by the authors)

However, what was even more important about the choice of linguistics as a platform for Soviet translatology was the fact that after 
the publication of Stalin's famous article "Marxism and the problems of linguistics" $(1950)^{9}$, Fedorov knew that a linguistic-based approach to translation would inevitably be affiliated to Stalin's work, which also made the approach ideologically infallible. Therefore, in 1953, Fedorov published his famous Vvedenie v teoriju perevoda [Introduction to the Theory of Translation], where he introduced certain principles for the Linguistic Translation Theory:

(1) Since translation always deals with languages, it should be studied in the linguistic context. The content of the source text does not exist in itself, but only in unity with the linguistic form and thus it can be transmitted in translation only with the help of linguistic means. (1953, p. 13; our trans. $)^{10}$

(2) [A] linguistic approach to the study of translation has the major advantage that it touches upon its very foundation, the language, without which no translation function exists, neither its social and political role, nor cultural and cognitive one, nor its artistic value, etc. (ibid.,p. 14; cited in Garbovskiy and Kostikova, 2012; trans. by the authors)

(3) It seemed that the application of linguistic methods would help to find objective and evidence-based guidelines "that would eliminate the subjective arbitrariness of a translator and references to 'intuition' as a justification of [the] translator's arbitrariness." (ibid., p. 12; cited in Garbovskiy and Kostikova, 2012)

(4) All sorts of studies and discussions about how translation reflected original content and what role it played for literature will be pointless unless they are based on an analysis of linguistic means of expression used in translation. (ibid., p. 14; cited in Garbovskiy and Kostikova, 2012)

(5) Theory and praxis are completely different, for their aims differ (like those of literature as art and the theory of literature as a scientific discipline). The theory of translation can therefore be the scientific basis of translating activity (ibid., p. 14; our trans.).

9. The article, which was supposedly written on behalf of Stalin by the Head of the Institute of Linguistics of the Russian Academy of Sciences Viktor Vinogradov, attacks the pseudo-scientific, albeit pro-Marxist, conception of Marrism. Marrism was an attempt of another academician, Nikolai Marr, to present languages as social superstructures-thus closely related to social classes, rather than to ethnic or cultural groups (see Alpatov, 1995).

10. Since the first publication in 1953, these principles have remained generally unchanged, except for the last statement about the link between the theory of translation and the philosophy of dialectical materialism (8) which was removed from the later editions of Fedorov's book together with the chapters on the contributions made to Russian translation science by Marx, Lenin and Stalin. Cf. Fedorov (2002, pp. 21-26). 
(6) Science implies the study of the regularities that exist in a field. The patterns identified can be used to draw conclusions that always allow variants. The translation theory must not impose them. The existence of regularities does not mean that the same translation model must always be applied, because the choice of a model depends on the given context. (ibid.; our trans.)

(7) The theory of translation, as a special branch of philological science, is, first of all, a linguistic discipline. However, in some cases, it resembles literary criticism, history and theory of literature $[. .$.$] and the history of$ those peoples whose languages it affects. (ibid.; our trans.)

(8) The Soviet theory of translation is based on the philosophy of dialectical materialism, which is the only paradigm capable of resolving the question of the relation between language and thinking. However, the connection that links the theory of translation with these sciences does not change its specificity as a linguistic discipline. (ibid.; our trans.)

When comparing his approach to the existing translation scholarship, Fedorov stated that "it is essential to notice the absence of any narrowly axiological dogmatism," meaning that the "breadth of evaluative judgments which are characteristic of [his] theory of translation" allows for wider inclusion of various approaches and points of view (cited in Witt, 2016, p. 54). As the linguistically informed translation theory proposed by Fedorov was based on an objective scientific foundation and supported by a vast corpus of empirical data, it proved to be fully compatible with the paradigm of Scientific Communism, which made it an eligible candidate for the Soviet theory of translation in the given historical and political context. ${ }^{11}$

\subsection{An Unrealistic Theory of "Realist" Translation}

The analytic approach advocated by Fedorov was not immediately praised by his peers. In fact, it was looked down on by the members of the Translation Division led by an eminent translator and literary critic Ivan Kashkin, who would insist on rejecting Fedorov's proposal and on combining translation theory with literary criticism instead of comparative linguistics. Moreover, as Division chair, Kashkin felt responsible for the development of Soviet translation theory and was not pleased with the idea of being sidelined by anyone else.

11. Which is reflected in the titles of some sections and chapters: "Classics of the revolutionary-democratic criticism on translation," "Marx, Engels and Lenin on translation," and "The outstanding problems of the theory of translation in the light of the works of Stalin in Linguistics." 
Consequently, right after the publication of Fedorov's Vvedenie v teoriju perevoda [Introduction to the Theory of Translation] Kashkin hastened to acknowledge the "need to develop a unified Soviet theory of translation closely related to the method of Socialist Realism" (1954a, p. 199; our trans.). Seeking a prescriptive theory to align with the cultural doctrine of Socialist Realism, Kashkin argued that such a theory "would provide reliable criteria for evaluating the work of translators, critics, and editors. It would further enhance the culture of translation and improve the skills of translators" (ibid.).

And so, Ivan Kashkin took the lead in the elaboration of a new Socialist theory of translation which he named "Teoriya realisticheskogo perevoda" [Theory of realist translation] by analogy to Socialist Realism. However, unlike Fedorov, Kashkin never managed to present his theory in any consolidated manner. In contrast to Fedorov's Introduction which appeared as a monograph, the ideas of Kashkin were left dispersed in his numerous publications in specialized periodicals. Nevertheless, once combined and analyzed, these publications may give an insight of what Kashkin might have implied by a "realist translation."

Foremost, Kashkin suggested narrowing the object of study to literary translation which, he claimed, "is subordinated not so much to linguistic as to literary regularities; hence, it is necessary to build a theory, or poetics of literary translation, on the basis and in terms of literary science" (1954c, p. 493; our trans.). Referring to translation as "poetics" and using literary criticism as its main theoretical framework was, on the one hand, a logical choice for a literary critic and literary translator like Kashkin. On the other hand, although narrowing the object of study to literary translation would inevitably limit the scope of his translation theory, his decision may be regarded as a strategic move that allowed Kashkin to win over the Translation Division of the Soviet Writers' Union by presenting his views within the continuum of Russian literary tradition, naturally including translation as a special form of literary production (see Baer, 2016). Trying to align his theoretical and political views with the general line of the Communist Party, Narkompros and the Writers' Union, Kashkin proclaimed that "Soviet translators, who form a detachment of Soviet literature, have the same goals, tasks and creative methods as all Soviet literati. This is the method of Socialist Realism" (1954a, p. 152; our trans.).

Although Kashkin had proclaimed Socialist Realism the main method of the Soviet school of translation, he did not provide clear 
indications as to what kind of translation could be called "realist." Instead, he confined himself to general speculations on how to interpret the tenets of Socialist Realism and apply them to translation. Here is a summary of Kashkin's views on the "realist" method:

The Soviet translator tries to see the phenomena, thoughts, things, actions and states behind the words of the source text, to live through them and then to faithfully reproduce the author's vision of reality. (Kashkin, 1953, p. 126; our trans.)

Realist translation truly conveys the content, but just as truthfully it must convey the form of the original which particularly reflects the national originality and the imprint of the epoch in its revolutionary development. (Kashkin, 1954b, p. 193; our trans.)

Translation is a very powerful medium of communication, but to be so, it must transmit the source text to the Soviet reader without alterations-truthfully, realistically and simply which means to translate with unobtrusive transparency. (ibid., pp. 196-197; our trans.)

Realist translation assumes a threefold but unified fidelity: fidelity to the original, fidelity to reality and fidelity to the reader. (Kashkin, 1953, p. 140; our trans.)

Undoubtedly, realist translation was an attempt to incorporate the official Soviet ideology into the theory of translation. As such, it was absolutely non-viable outside the framework of Socialist Realism and it stirred up criticism toward Kashkin and his theory. The obvious vulnerability of Kashkin's views consisted in "addressing translation as an independent artistic reinterpretation of reality, rather than a secondary literary presentation of the author and his text" (Azov, 2012, p. 144; our trans.). Additionally, the proposed theory, which consisted in reproducing reality, seemed to deliberately ignore the cases of literary works whose main aesthetic task was to distort reality (Friedberg, 1997, pp.106-107). Upon discussion of the translation method behind Kashkin's theory, it was noted that "a theory that ignores the linguistic form of a literary work only disarms the translator" (Etkind, 1963, p. 135; our trans.).

\subsection{Ideological Failure of Realist Translation}

In response to the criticism of his theory of translation, Kashkin launched an extensive publishing campaign in which he criticized his rivals, their theory, and the linguistic approach to translation in general. With the support of the Writers' Union, he published a series of articles where he presented the competition between the two 
approaches as a "struggle" for the future of literary translation and, by extension, Soviet translation in general (Kashkin, 1953). Insisting on the literary nature of translation and translatology, Kashkin criticized Fedorov for depriving translators of freedom and creativity. Moreover, he argued that Fedorov's book was "to a certain extent, a book for artisans, a handicraft book, not for masters" (cited in Azov, 2013, p. 36; our trans.). Surprisingly, in his rigorous criticism, Kashkin discarded Fedorov's admission about the inapplicability of the linguistic approach to literary translation:

Of course, it is impossible to explain translation exclusively from a linguistic viewpoint. Especially when it comes to the translator's attitude toward the content of the source text or when it comes to the interpretation of that content. [...] Such cases are due to the ideology and aesthetics of either the translator or the literary movement. As far as literary translation is concerned, it is an art and thus it does not tolerate any standardized decision. (Fedorov, 2002, p. 24; our trans.)

In his desire to crush Fedorov, Kashkin would soon become so paranoid that even his companions admitted that their leader, being "a man of great talent, squandered it for the unworthy attacks against his adversaries" (Lyubimov, 2004, p. 343; our trans.). However, the fatal blow for the "realist" method was due to Kashkin's disregard for the very important defensive remark which Fedorov had left in his book, namely in the chapter "The outstanding problems of the theory of translation in light of the works of Stalin in linguistics"12:

We must also struggle with ideological perversions in the work of translators and with the attempts to theoretically justify any arbitrariness in the field of translation, with the vestiges of Marrist conceptions manifested in their depreciation of the role of language in translation and in questioning the very possibility and the perspectives of the linguistic approach to translation. (Fedorov, 1953, p. 102; our trans.)

It was clear to everyone, except perhaps Kashkin, that after such a remark, any criticism of the linguistic approach could have been interpreted as criticism against Stalin. Furthermore, by the end of the 1950s, Fedorov's Introduction to the Theory of Translation, which seemed to meet all the expectations of state authorities, had already become the official handbook for Soviet translators and interpreters. Thus, Soviet translatology took a linguistic turn which, for the lack of

12. This is a reference to the above-mentioned Stalin article "Marxism and the problems of linguistics" (1950). 
any serious rivalry from Literary or Cultural Studies avant la lettre, remained the only serious paradigm shift in the history of Russian translation science. Within the linguistic paradigm, translators could not be recognized as authors, even secondary, but rather as "the engineers of human souls" (Stalin), or as Pushkin once called them, "the post-horses of enlightenment" (cited in Witt, 2011, p. 155). While linguistic paradigms continued to establish their dominance in the institutionalized field of Soviet translation and translatology, a few followers of Kashkin, still loyal to the ideas of Realist translation, became lone enthusiasts due to the important lack of institutionalized support. And, although it would be incorrect to assert that the longstanding tradition of Russian literary translation stopped completely with the failure of the Kashkinists, it would be difficult to deny that since the 1950s, the literary approach to translation in Russia has never come close to regaining its past supremacy over the linguistically informed theory of translation.

\section{Conclusion}

This article investigates one of the most controversial aspects of translation-its manipulative potential and the ways in which it was used and abused for the advancement of political, economic and cultural causes. We have discussed the role of translation in different imperial projects in close association with various forms of dictatorship, on the one hand, and oppression on the other. In order to establish and maintain a political and cultural dictatorship, a forcible introduction to a new regime may not be sufficient. To ensure that the changes are deeply rooted in the social fabric and accepted by the population, an intervention into the mass' mindset may also be required. As we have demonstrated in our paper, the latter is usually achieved through various culture-planning operations or even larger projects of mass cultural reorientation supported by a particular ideology.

We have made an attempt to touch upon the essence of the projects of mass cultural reorientation and we proposed our vision of these political and cultural phenomena, elaborating on the case of Russian national history. By analyzing the historical development of Russian statehood and evolution of its national identity through three consecutive cultural shifts, we have identified the main socioeconomic and political objectives of the most recent upheaval in Russian history-the Great October Revolution followed by the creation of the first Socialist state. We have discussed that to ensure the 
stability of the new regime, the Communist Party needed to educate the masses in order to replace the imperial identity with a proletarian one, suppress nationalist sentiments, and indoctrinate people with the Communist ideology. All that was achieved through pervasive literacy campaigns and the creation of a new cultural environment.

In the meantime, translation had to contribute to the creation of a new cultural canon of Socialist Realism and to become the main tool for the revisionist policies adopted by the Soviet regime. Through the analysis of certain Soviet translation projects, we have explained how the ongoing disputes surrounding translation policies and the conformist translation method resulted in the confrontation between two Soviet schools of thought advocating for different ways of theorizing and practising translation: one supported the linguistic approach, while the other believed in the literary one. By framing our comparative analysis of the two schools within the context of Soviet totalitarianism, we have demonstrated how each of the schools manipulated the official state ideology in their struggle for recognition. In the Soviet ideological context, the linguistic approach built upon the theoretical and methodological foundation of structural linguistics was deemed more appropriate than the literary approach advocating for "realist translation," which was non-viable outside the framework of Socialist Realism. For the reason of theoretical objectivity and ideological conformity, the linguistic approach to translation came to represent the dominant theoretical framework of Soviet translation science, thus relegating to oblivion the "realist" approach to translation.

\section{References}

Alpatov, Vladimir M. (1995). "Marr, Marrism, and Stalinism." Russian Studies in History, 34, 2, pp. 37-61.

Anisimov, Evgenii V. (2015 [1993]). The Reforms of Peter the Great: Progress Through Coercion in Russia. Trans. J. T. Alexander. London and New York, Routledge.

Asagba, Austin (2011). Cultural Reorientation, Peace Building \& National Development. Abuja, Nigeria, National Institute for Cultural Orientation.

Azov, Andrey (2012). "K istorii teorii perevoda v Sovetskom Sojuze. Problema realisticheskogo perevoda [The History of Translation Theory in the Soviet Union. The Problem of Realist Translation]." Logos, 3, 87, pp. 131-152.

Azov, Andrey (2013). Poverzhennye bukvalisty. Iz istorii hudozhestvennogo perevoda v SSSR v 1920-1960-e gody [Defeated Literalists. The History of Literary Translation in the USSR in the 1920-1960s]. Moscow, High School of Economics. 
Baer, Brian James. (2016). Translation and the Making of Modern Russian Literature. New York and London, Bloomsbury.

Balliu, Christian (2005). "Clefs pour une histoire de la traductologie soviétique.” Meta, 50, 3, pp. 934-948.

Berghahn, Volker R. (2006). "The Allies and the Reorientation of German Culture after 1945.” Diplomatic History, 30, 3, pp. 545-548.

Bogdanov, Alexander. (1924). O proletarskoj kulture 1904-1924 [On the Proletarian Culture]. Moscow/Leningrad, Kniga.

Bourdieu, Pierre (1990). "Structures, Habitus, Practices." In The Logic of Practice. Cambridge, Polity, pp. 52-65.

Braman, Donald et al. (2005). "The 'Wildavsky Heuristic': The Cultural Orientation of Mass Political Opinion." GW Law Faculty Publications E Other Works, Paper 202.

Brown, Deming (1962). Soviet Attitudes toward American Writing. Princeton, Princeton University Press.

Cannon, James P. (1924). "The Bolshevization of the Party." The Workers Monthly, 4, pp. 34-37.

Chukovsky, Kornei and Nikolay Gumilev (1919). Principy kbudozhestvennogo perevoda [The Principles of Literary Translation]. Petrograd, Vsemirnaja literatura.

Chukovsky, Kornei and Andrei Fedorov (1930). Iskusstvo perevoda [Art of Translation]. Leningrad, Academia.

Cross, Samuel H. and Olgerd P. Sherbowitz-Wetzor, eds. (1953). The Russian Primary Chronicle: Laurentian Text (Lavrenterskaia letopis'). Cambridge, MA, Mediaeval Academy of America.

Etkind, Efim G. (1963). Poeziya i perevod [Poetry and Translation]. Leningrad, Sovetskii pisatel.

Even-Zohar, Itamar (2002). "Culture Planning and Cultural Resistance." Sun Yat-Sen Journal of Humanities, 14, pp. 45-52.

Fedorov, Andrei V. (1941). O khudozhestvennom perevode [On the Literary Translation]. Leningrad, Gos. izd-vo khudozh. lit-ry.

Fedorov, Andrei V. (1953). Vvedenie v teoriju perevoda [Introduction to the Theory of Translation]. Moscow, Izdatelstvo literatury na inostrannyh yazykah.

Fedorov, Andrei V. (2002 [1953]). Osnovy obščej teorii perevodovedenija (Lingristiceskije problemy) [The Fundamentals of the General Theory of Translation (Linguistic Problems)]. St. Petersbourg/Moscow, SpbGU/ Philologia Tri.

Fitzpatrick, Sheila (2002). The Commissariat of Enlightenment: Soviet Organization of Education and the Arts under Lunacharsky, October 19171921. Vol. 2. Cambridge, Cambridge University Press.

Fokin, Sergey L. (2016). "Perevod, perevodimost' i neperevodimost' v svete formalisticheskoj teorii. O rannih rabotah A. V. Fedorova (Translation, Translatability and Untranslatability in the Light of Formalistic Theory. On the Early Works of A. V. Fyodorov)." Voprosy literatury. The Journal of Literary Criticism, 1, pp. 154-175. 
Friedberg, Maurice (1997). Literary Translation in Russia: A Cultural History. University Park, Penn State University Press.

Garbovskiy, Nikolay and Olga Kostikova (2012). "Science of Translation Today: Change of Scientific Paradigm.” Meta, 57, 1, pp. 48-66.

Gorky, Maxim (1919). Catalog izdatelstva "Vsemirnaya literatura" [Catalog of the Vsemirnaya Literatura Publishers]. Petrograd, Vsemirnaya Literatura.

Gorky, Maxim (1955). O literature: literaturno-kritičeskie stat’i [On Literature: Articles on Literary Criticism]. Moscow, Sovetskij pisatel'.

Higham, John (2001). "The Reorientation of American Culture in the 1890s [1965]." In J. Higham and G. Carl, eds. Hanging Together: Unity and Diversity in American Culture. New Haven, Yale University Press, pp. 173198.

Kashkin, Ivan A. (1953). "V bor'be za realisticheskij perevod [The Struggle for a Realist Translation].” In Voprosy khudozhestvennogo perevoda [Issues of the Literary Translation]. Moscow, Sovetskij pisatel, pp. 120-165.

Kashkin, Ivan A. (1954a). "O metode i shkole sovetskogo hudozhestvennogo perevoda [On the Method and School of the Soviet Literary Translation]." Znamya, 10, pp. 141-153.

Kashkin, Ivan A. (1954b). "O realizme v sovetskom hudozhestvennom perevode [On Realism in the Soviet Literary Translation]." Drouzhba narodov, 4, pp. 188-199.

Kashkin, Ivan A. (1954c). "Voprosy perevoda [Problems of Translation].” In $V$ bratskom edinstve. Nekotorye voprosy pazvitija literatur narodov SSSR [Fraternal Unity. The outstanding Issues of the Development of the Literatures of the Peoples of the USSR]. Sovestkij pisatel, pp. 476-512.

Khān, Yāsmīn (2001). Cultural Reorientation in Society. New Delhi, Mittal Publications.

Kliuchevsky, Vassily O. (1937). Kurs russkoj istorii [A Course in Russian History] (1911). Moscow, Sozekgiz.

Lebedev-Polyansky, Platon (1918). "Revolution and the Cultural Tasks of the Proletariat.” In W. G. Rosenberg, ed. Bolshevik Visions: First Phase of the Cultural Revolution in Soviet Russia (1990). Vol. 1. Ann Arbor, University of Michigan Press, pp. 50-58.

Lenin, Vladimir I. (1901). "What is to be Done? The Burning Question of Our Movement.”Trans. J. Fineberg and G. Hanna. In Lenin's Selected Works (1964). Vol. 1. Moscow, Progress Publishers, pp. 119-127. [https://www. marxists.org/archive/lenin/works/1901/witbd/ch03.htm].

Lenin, Vladimir I. (1905). "New Tasks and New Forces.”Trans. B. Isaacs and I. Lasker. In Lenin Collected Works (1962). Vol. 8. Moscow, Foreign Languages Publishing House, pp. 209-220. [https:/www.marxists.org/archive/lenin/ works/1905/mar/08.htm].

Lenin, Vladimir I. (1917a). “The State and Revolution.”Trans. Anon. In Lenin's Collected Work (1964). Vol. 25. Moscow, Progress, pp. 381-492. [https:// www.marxists.org/archive/lenin/works/1917/staterev/ch02.htm]. 
Lenin, Vladimir I. (1917b). "The Tasks of the Proletariat in Our Revolution. Draft Platform for the Proletarian Party." Trans. I. Bernard. In Lenin Collected Works (1964). Vol. 24. Moscow, Progress Publishers, pp. 55-92. [https://www.marxists.org/archive/lenin/works/1917/tasks/index.htm].

Lenin, Vladimir I. (1920). “On Proletarian Culture. Draft Resolution.”Trans. J. Katzer. In Lenin's Collected Works (1965). 4th English ed. Vol. 31. Moscow, Progress Publishers, pp. 316-317. [https://www.marxists.org/archive/lenin/ works/1920/oct/08.htm\#fw01].

Lenin, Vladimir I. (1965). Collected Works. Moscow, Progress Publishers.

Lenin, Vladimir I. (1972). "The Achievements and Difficulties of the Soviet Government." Trans. G. Hanna. In Collected Works. $4^{\text {th }}$ English ed. Vol. 29. Moscow, Progress Publishers, pp. 55-88. [https://www.marxists.org/ archive/lenin/works/1919/mar/x01.htm].

Lenin, Vladimir I. and Todd Chretien (2014). State and Revolution. Chicago, Haymarket Books.

Levin, A. D. (1962). "Vsemirnaya literatura." In A. A. Surkov, ed. Kratkaja literaturnaja enciklopedija [Brief Literary Encyclopedia]. Vol. 1. Moscow, Sovetskaya enciclopedia. [http://feb-web.ru/feb/kle/kle-abc/ke1/ke1-a593. htm].

Luppol, L. K., M. M. Rozental and S. M. Tretiakov, eds. (1990 [1934]). Pervyj vsesoyuznyj s'ezd sovetskih pisatelej, stenograficheskij otchet [The First All-union Congress of Soviet Writers, Stenographic Report]. Moscow, Sovetskij pisatel.

Lyubimov, Nikolai M. (2004). Neuvjadaemyj cvet: Kniga vospominanij [The Unfading Blossom: The Book of Memories]. Vol. 2. Moscow, Yazyki russkoj kultury.

Marxists Internet Archive (n.d.). Marxists Internet Archive. [https://www. marxists.org/].

Morson, Gary Saul (1979). "Socialist Realism and Literary Theory." The Journal of Aesthetics and Art Criticism, 38, 2, pp. 121-133.

Nelson, Cary and Lawrence Grossberg (1988). Marxism and the Interpretation of Culture. Urbana, University of Illinois Press.

Radek, Karl (1934). Contemporary World Literature and the Tasks of Proletarian Art. Soviet Writers' Congress 1934. London, Lawrence \& Wishart, pp. 73182. [https://www.marxists.org/archive/radek/1934/sovietwritercongress. $\mathrm{htm}]$.

Stalin, Joseph V. (1920). "The Policy of the Soviet Government on the National Question in Russia." In Works. November, 1917-1920 (1953) (Vol. 4). Moscow, Foreign Languages Publishing House.

Stalin, Joseph V. (1978 [1938]). "On the Final Victory of Socialism in the U.S.S.R.”Trans. Anon. In Collected Works. Vol. 14. London, Red Star Press.

Stalin, Joseph (1950). "Marksizm i problemy yazykoznaniya [Marxism and Problems of Linguistics]." Pravda, June 20.

Stetsky, Alexey I. (1934). "Under the Flag of the Soviets, under the Flag of Socialism."In Soviet Writers Congress.London,Lawrence \&Wishart,pp. 261- 
274. [https://www.marxists.org/subject/art/lit_crit/sovietwritercongress /stetsky.htm].

Toury, Gideon (2005). "Enhancing Cultural Changes by Means of Fictitious Translations." In E. Hung, ed. Translation and Cultural Change: Studies in History, Norms and Image-projection. Amsterdam, John Benjamins, pp. 3-17. Trotsky, Leon (1925). Literature and Revolution. Trans. R. Strunsky. Chicago, Haymarket Books.

Witt, Susanna (2011). "Between the Lines. Totalitarianism and Translation in the USSR.” In B. J. Baer, ed. Contexts, Subtexts and Pretexts: Literary Translation in Eastern Europe and Russia. Amsterdam, John Benjamins, pp. 149-170.

Witt, Susanna (2016). "Socialist Realism in Translation: The Theory of a Practice.” Baltic Worlds, IX, 4, pp. 52-58.

\section{Gleb Dmitrienko}

Département de linguistique et de traduction Université de Montréal Montréal (Québec), Canada gleb.dmitrienko@umontreal.ca 